\title{
STUDY OF NUTRITIONAI REQUIREMENTS AND GROWTH \\ OF Penaeus merguiensis IN TANKS BY MEANS \\ OF PURIFIED AND ARTIFICIAL DIETS
}

\author{
AQUACOP 1 \\ Centre Océanologique du Pacifique \\ B.P. 7004 Taravao \\ Tahiti, Polynésie Française
}

\begin{abstract}
- One of the criteria for selecting a shrimp of commercial interest in French Polynesia is the acceptability of artificial diet; such a criterion has been used to test Penaeus merguiensis. Experiments have been carried out in Centre Océanologique du Pacifique in Tahiti island where the water temperature range is $25-29^{\circ} \mathrm{C}$, salinity $35 \mathrm{ppt}$, pH. 8.2, and photoperiod constant. Juveniles used in this study are hatched in CNEXO-COP at Vairao. It has been found that a 50-55 protein content diet gives a better growth performance. A carbohydrate such as starch appears more suitable than glucose or glucose plus starch in isonitrogenous purified diets. A vitamin mix rich in vitamin $C$, choline and inositol provides better results and a mineral mix with 38 magnesium reaches optimum. The major nutritional results for this species are applied to formulation of artificial diets. With the best diet, growth performances are normal: from $2.8 \mathrm{~g}$ to $9.0 \mathrm{~g}$ in 90 days, with about 60 survival rate at a low density, 20 animals $/ \mathrm{m}^{2}$ under strict control. But at another scale, in $400 \mathrm{~m}^{2}$ grow-out tanks, growth was rather low even with an excellent Japanese diet containing 60 protein. Therefore, P. merguiensis does not appear to be a good candidate species for aquafarming in French Polynesia. -
\end{abstract}

\section{INTRODUCTION}

Tropical areas seem to be propitious for development of penaeid shrimp farming. Recent research in the field shows different results among species as to growth promotion (Aquacop, 1976). Some attempts have been made with Penaeus merguiensis involving field observations (Gundermann and Popper, 1975) and laboratory experiments (Beard et al.,

1 Nutrition: G. Cuzon (new address: Centre Océanologique de Bretagne, B.P. 337, 29273 Brest Cedex, France), A. Febvre, J. Mélard, G. Parker, G. Fagnoni; Water Control: J. Calvas; Rearing Technique: J. M. Griessinger, P. Hatt, G. Poullaouec; Pathology: J. F. Le Bitoux; Algae Culture: J. L. Martin; Program Coordinator: A. Michel. 
1977) in recirculation systems. An important literature review on nutritional requirements of shrimps and prawns is available (New, 1976). The following report presents the results obtained in the Centre Océanologique du Pacifique in French Polynesia within the scope of nutritional requirements and potentialities for growth on artificial food in a mariculture situation.

\section{MATERIALS AND METHODS}

The spawners of Penaeus merguiensis were introduced into Tahiti from New Caledonia and their reproduction in captivity was successful (Aquacop, 1975). Juveniles were selected from 3-8 $\mathrm{g}$ to carry out the growth tests in tanks of 80-100 liters in a water flow system at an average temperature of $27^{\circ} \mathrm{C}, 34.5 \mathrm{ppt}$ salinity, pH 8.2 and a constant photoperiod. Animals were randomized inside the different tanks and trials were conducted in duplicate with 12-15 animals per tank. Live animal weight was determined at beginning and end of each 30-day feeding trial. Wet weights were determined with the use of a Mettler top loading balance weighing to $.01 \mathrm{~g}$. The $t$-test was used to compare individual growth and the chi-square to compare survival data (Schwartz, 1963). The food was distributed at 5:00 P.M. and pellet remains removed in the morning. The technique for preparing purified diets is similar to that of Kanazawa et al. (1970). Artificial diets are made by adding water to the mixture of finely ground feedstuffs to obtain noodles with a meat grinding apparatus; drying occurs 10-12 hours before storage. Basal composttion of the purified diet is given in Table 1 . The compositions of vitamin mixture used in this paper are given in Table 2. Several mineral mixtures used to determine the optimum magnesium in the diet are given in Table 3. Circular fiberglass tanks used have been described previously (Aquacop, 1977b).

Table 1. Basal Composition of Purified Diets Used to Study Protein Requirements with $P$. merguiensis

\begin{tabular}{llllrr}
\hline Casein (8) & 29 & 39 & 44 & 49 & 55 \\
Cellulose (8) & 26 & 16 & 11 & 6 & 0
\end{tabular}

Constant part of the diets (8): glucose 4.2 , sucrose 4.2, starch 5.4, Na citrate 0.3 , Na succinate 0.3 , cholesterol 2, cod liver oil 7, protector vitamin mix 9.8 , mineral mix 8 , agar 3

\section{RESULTS}

An experiment was carried out by means of purified diets at different protein levels. The optimum appears at 43-558 protein content. Animals growing from 1-2 $\mathrm{g}$ average weight in one month with 608 survival rate and individual final weight are considered for statistics. A second set of experiments using purified casein basal diets and several polysaccharides (Table 4) was conducted in small circular tanks. Although the growth rate is very low in this set of experiments, the best average weight is obtained with 558 protein content; for a similar level 
of proteins, results are significantly superior $(p<.05)$ when polysaccharides are incorporated into the diet rather than monosaccharides.

Table 2. Composition of Two Vitamin Mixes (mg/kg Dry Diet) Used for Shrimp Diet in This Study

\begin{tabular}{lrr}
\hline \multirow{2}{*}{ Vitamin } & \multicolumn{2}{c}{ Vitamin } \\
\cline { 2 - 3 } & No. & No. \\
\hline A & 80,000 & - \\
D & 8,000 & 24,000 \\
E & 150 & 110 \\
Menadione & 8 & 20 \\
C & 600 & 20,000 \\
Thiamine & 18 & 20 \\
B2 & 16 & 40 \\
Niacin & 400 & 200 \\
Calcium pantothenate & 200 & 300 \\
Pyridoxine hydrochloride & 16 & 60 \\
Folic acid & 17 & 4 \\
B12 & 0.04 & 0.4 \\
Biotin & 0.02 & 2 \\
Choline chloride & 800 & 3,000 \\
Inositol & 60 & 2,000 \\
Paraminobenzoic acid & & 50 \\
\hline
\end{tabular}

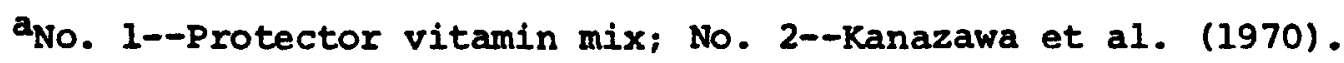

Table 3. Composition of Mineral Mixes Used in This Study

\begin{tabular}{lcccc}
\hline & \multicolumn{5}{c}{ Premix } & Number \\
\cline { 2 - 5 } & 1 & 2 & 3 & 4 \\
\hline $\mathrm{K}_{2} \mathrm{HPO}_{4}$ & 2.0 & 2.0 & 2.0 & 2.5 \\
$\mathrm{CaHPO}_{4}$ & 2.7 & 2.7 & 2.7 & - \\
$\mathrm{NaH}_{2} \mathrm{PO}_{4}$ & 0.8 & 0.8 & 0.8 & - \\
$\mathrm{MgSO}_{4}$ & 1.0 & 3.0 & 5.0 & - \\
$\mathrm{CaCO}_{3}$ & - & - & - & 1.0 \\
$\left(\mathrm{C}_{3} \mathrm{H}_{5} \mathrm{O}_{3}\right)_{2} \mathrm{Ca}_{5} \mathrm{H}_{2} \mathrm{O}$ & - & - & - & 6.5 \\
$\mathrm{MnSO}_{4}$ & 0.04 & 0.04 & - & - \\
$\mathrm{Cellulose}^{\text {Total premix }}$ & 4.0 & 2.0 & - & - \\
inclusion (8) & 10.5 & 10.5 & 10.5 & 10.5 \\
\hline
\end{tabular}

apremix No. 4 is the MacCollum's salt. 
Table 4. Percentages of Average Weight Increase in 30 Days with Casein Basal Diets Containing Several Kinds of Carbohydrates in Equal Part

\begin{tabular}{llllll}
\hline & \multicolumn{4}{c}{ Diet Number } \\
\cline { 3 - 6 } & I & II & III & IV \\
\hline Casein (8) & 29 & 39 & 49 & 55 \\
Weight increase in : & & & & \\
& m 1 & 12 & 5 & 3 & $6^{*}$ \\
Survival rate in : & m 2 & 13 & 18 & 19 & $35^{*}$ \\
& m 1 & $63 a$ & $57 a$ & $81 \mathrm{a}$ & $34 \mathrm{~b}$ \\
& m 2 & $35 \mathrm{a}$ & $53 \mathrm{a}$ & $44 \mathrm{a}$ & $53 \mathrm{a}$ \\
\hline
\end{tabular}

m 1--starch 8.4 , glucose 4.2 , sucrose 4.2 ; m 2--starch 12.6 , sucrose 4.2 .

* denotes numbers significantly different. Line 5--numbers bearing a different letter are significantly different (chi-square, 15.46). Line 6--numbers are not significantiy different (chi-square, 2.93).

In order to improve the growth and survival rates, an antibiotic (aureomycin) at a level of 0.028 is added to purified diets with 508 casein content. Comparative growth tests on 30 days with juveniles of $1.3 \mathrm{~g}$ average starting weight do not yield a significantly higher survival rate (chi-square $=2.13$ ) with antibiotic supplement (Table 5). To determine the best source of lipids for incorporation into the casein basal diet, several tests have been carried out. Two vegetable oils and 2 fish oils and a mixture of both were tested at a level of 78 in the diet. After one month of the experiment, the cod liver oil provided a growth rate of 608 and a survival rate of 638 significantly increased (Table 6).

Table 5. Effect of Antibiotic Supplementation on Performance of Penaeus merguiensis

\begin{tabular}{lcccccc}
\hline & $\begin{array}{c}\text { Initial } \\
\text { Number }\end{array}$ & $\begin{array}{c}\text { Survival } \\
\text { Rate } \\
(8)\end{array}$ & $\begin{array}{c}\text { Average } \\
\text { Initial } \\
(g)\end{array}$ & $\begin{array}{c}\text { Final } \\
\text { Weight } \\
(g)\end{array}$ & SD & $\begin{array}{c}\text { Growth } \\
\text { Rate } \\
(8)\end{array}$ \\
\hline Standard formula & 34 & $38 a$ & $1.47 a$ & 3.0 & .53 & $101 a$ \\
0.28 aureomycin added & 34 & $55 a$ & $1.23 a$ & 2.24 & .49 & $83 a$ \\
\hline
\end{tabular}

SD - standard deviation of the mean. Numbers bearing the same letter are not significantly different.

The mineral mixture of optimum casein basal diet for Penaeus merguiensis is elaborated with 3 magnesium concentrations: 1,3 and 5\%. A one-month growth rate test gave a range of survival rate of 14-80z and a growth performance of 808 with $38 \mathrm{MgSO}_{4}$ in the mineral mixture (Table 7). 
Table 6. Influence of Dietary Lipids on Growth and Survival of Penaeus merguiensis

\begin{tabular}{lcccccc}
$\begin{array}{c}\text { Lipids Added } \\
\text { to Diet }\end{array}$ & $\begin{array}{c}\text { Initial } \\
\text { Number }\end{array}$ & $\begin{array}{c}\text { Survival } \\
\text { Rate } \\
(8)\end{array}$ & $\begin{array}{c}\text { Average } \\
\text { Initial } \\
(\mathrm{g})\end{array}$ & $\begin{array}{c}\text { Final } \\
\text { Weight } \\
(\mathrm{g})\end{array}$ & $\begin{array}{c}\text { SD } \\
\begin{array}{c}\text { Growth } \\
\text { Rate } \\
(8)\end{array}\end{array}$ \\
\hline $\begin{array}{l}\text { Soya bean oil } \\
\text { Linseed oil }\end{array}$ & 30 & $40 \mathrm{a}$ & 1.36 & 1.94 & .39 & $43 \mathrm{a}$ \\
$\begin{array}{l}\text { Shark oil } \\
\text { Linseed oil and cod }\end{array}$ & 30 & $42 \mathrm{a}$ & 1.28 & 1.75 & .33 & $37 \mathrm{a}$ \\
liver oil & 30 & $50 \mathrm{a}$ & 1.35 & 1.95 & .45 & $44 \mathrm{a}$ \\
Cod liver oil & 30 & $42 \mathrm{a}$ & 1.30 & 1.79 & .26 & $37 \mathrm{a}$ \\
\hline
\end{tabular}

SD = standard deviation of the mean; numbers bearing the same index in the same column are not significantly different at 0.05 .

Table 7. Growth Performance Using Different Mineral Mixtures in a Purified Diet

\begin{tabular}{lcccccc}
\hline $\begin{array}{l}\text { Mineral } \\
\text { Mixture }\end{array}$ & $\begin{array}{c}\text { Initial } \\
\text { Number }\end{array}$ & $\begin{array}{c}\text { Survival } \\
\text { Rate } \\
(8)\end{array}$ & $\begin{array}{c}\text { Average } \\
\text { Initial } \\
(g)\end{array}$ & $\begin{array}{c}\text { Final } \\
\text { Weight } \\
(g)\end{array}$ & sd & $\begin{array}{c}\text { Growth } \\
\text { Rate } \\
(8)\end{array}$ \\
\hline Premix A & 28 & $68 \mathrm{a}$ & .50 & .93 & .46 & $88 \mathrm{a}$ \\
Premix B & 29 & $79 \mathrm{~b}$ & .52 & .80 & .19 & $53 \mathrm{~b}$ \\
Premix C & 28 & $14 \mathrm{c}$ & .47 & .75 & .29 & $59 \mathrm{~b}$ \\
McCollum's salt & 28 & $80 \mathrm{~b}$ & .56 & .80 & .27 & $42 \mathrm{~b}$ \\
\hline
\end{tabular}

For survival rate: numbers bearing the same letter are not significantly different at the 58 level. For growth rate, $F=3.57$ $(p<0.05)$.

A last set of experiments was made using several vitamin mixtures (Table 8 ) in a 558 casein basal diet and 18.68 corn starch. Feed consumption reached 70-878 after one month. Mixture No. 2 provides a good survival rate, 638 , but the growth rate is not significantly different from the others $(p>.05)$. Mixture No. 4 gives a survival rate significantly lower than premix No. 3 where vitamin $C$ is added (chi-square = 6.7).

The second step was to formulate an artificial diet which could give enough growth promoting effect on shrimp. First we tried to formulate different diets with 508 protein content with (V2, V3) or without fish protein concentrate (FPC)V1, V5; with (V3, V5) or without (V1, V2) cod liver oil added, with (V5) or without (V1, V2, V3) vitamin supplement. Basal composition was shrimp meal, FPC, Norway fish meal, wheat gluten, spirulina, and yeast.

The best growth curve is shown on Figure 1, curve No. 1. A $50 \%$ protein content diet has provided a growth promotion from 2.7 to $9.1 \mathrm{~g}$ in 12 weeks or $.53 \mathrm{~g}$ per week. Some shrimp in the pool have increased at $.78 \mathrm{~g}$ per week $(3.3$ to $12.6 \mathrm{~g})$ during the same period. An estimated ratio is $1.4: 1$ (Table 9). 
Table 8. Zootechnical Results obtained with Several Vitamin Premixes (for each column, numbers bearing the same index are not significantly different)

\begin{tabular}{ccccccc}
\hline $\begin{array}{l}\text { Vitamin } \\
\text { Mixture }\end{array}$ & $\begin{array}{c}\text { Initial } \\
\text { Number }\end{array}$ & $\begin{array}{c}\text { Survival } \\
\text { Rate } \\
(8)\end{array}$ & $\begin{array}{c}\text { Average } \\
\text { Initial } \\
(\mathrm{g})\end{array}$ & $\begin{array}{c}\text { Final } \\
\text { Weight } \\
(\mathrm{g})\end{array}$ & SD & $\begin{array}{c}\text { Growth } \\
\text { Rate } \\
(8)\end{array}$ \\
\hline 1 & 32 & $56 \mathrm{a}$ & 1.12 & 1.71 & .30 & $54 \mathrm{a}$ \\
2 & 32 & $63 \mathrm{a}$ & 1.10 & 1.77 & .33 & $60 \mathrm{a}$ \\
3 & 32 & $63 \mathrm{a}$ & 1.18 & 1.84 & .39 & $56 \mathrm{a}$ \\
4 & 32 & $50 \mathrm{~b}$ & 1.12 & 1.73 & .29 & $55 \mathrm{a}$ \\
5 & 32 & $22 \mathrm{c}$ & 1.13 & 1.51 & .19 & $34 \mathrm{~b}$ \\
6 & 32 & $44 \mathrm{~b}$ & 1.11 & 1.66 & .34 & $50 \mathrm{a}$ \\
\hline
\end{tabular}

No. 1--Protector (z. I. Elancourt, 78190 Trappes); No. 2--Kanazawa (1970); No. 3--Protector enriched with vitamin C, inositol, choline; No. 4--Protector enriched with inositol, choline; No. 5--Vitamin mixture for pigs; No. 6--Vitamin fortification mixture (Cleveland, Ohio USA).

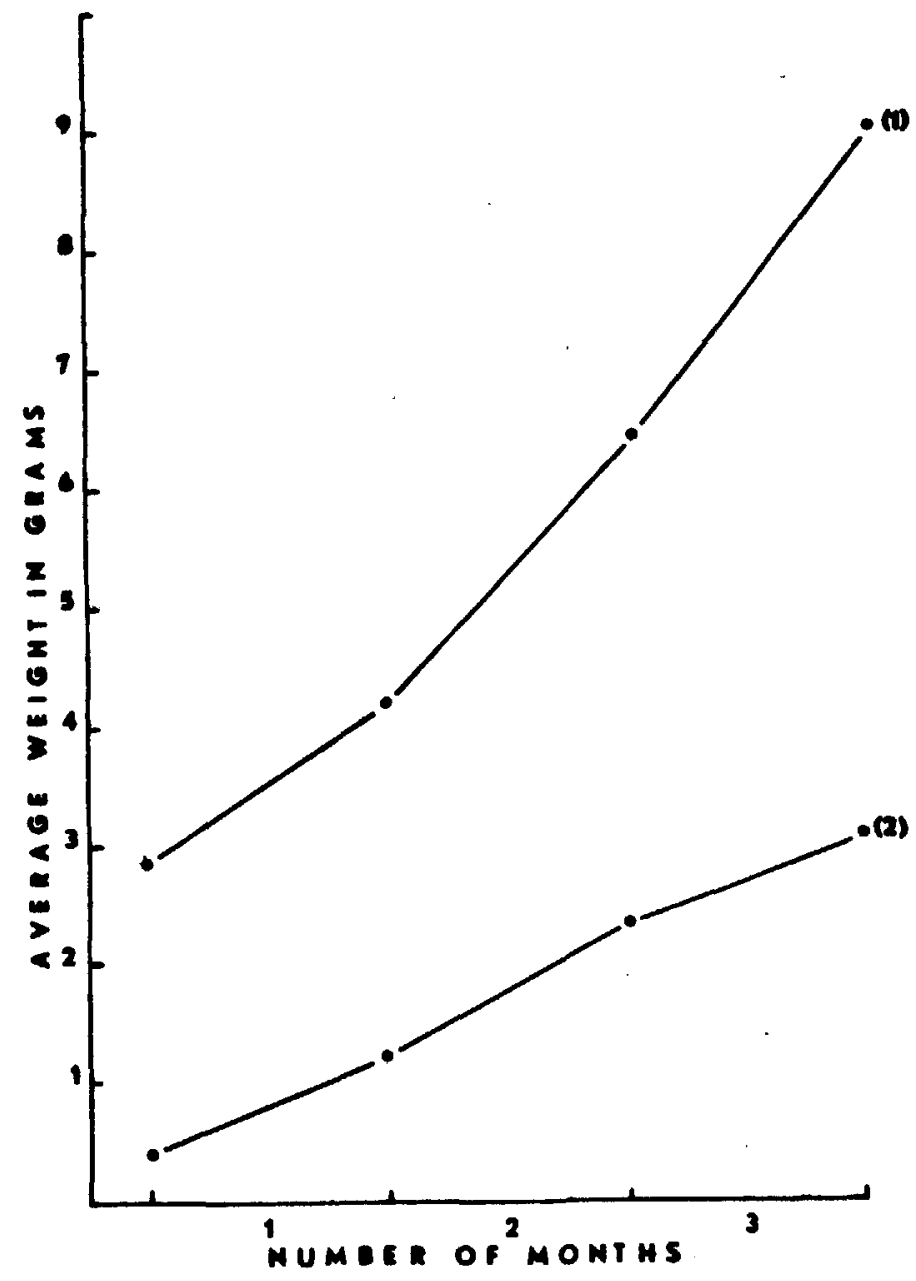

Figure 1. Results of growth with Penaeus merguiensis in $1 \mathrm{~m}^{2}$ tank on artificial diet. Curve 1 is obtained with a 50 protein diet (V3). The same diet (curve 2) is used as a reference in attempts for various protein supplementations. 
Table 9. Results of a 12-Week Feeding Test

\begin{tabular}{lcccccc}
\hline $\begin{array}{c}\text { Diet } \\
\text { Number }\end{array}$ & $\begin{array}{c}\text { Initial } \\
\text { Number }\end{array}$ & $\begin{array}{c}\text { Survival } \\
\text { Rate } \\
(8)\end{array}$ & $\begin{array}{c}\text { Average } \\
\text { Initial } \\
(g)\end{array}$ & $\begin{array}{c}\text { Final } \\
\text { Weight } \\
(g)\end{array}$ & SD & $\begin{array}{c}\text { Growth } \\
\text { Rate } \\
(8)\end{array}$ \\
\hline V1 & 40 & $50 \mathrm{a}$ & 2.6 & 6.4 & 1.39 & $141 \mathrm{a}$ \\
V2 & 40 & $35 \mathrm{~b}$ & 3.2 & 8.4 & 1.25 & $160 \mathrm{~b}$ \\
V3 & 40 & $58 \mathrm{a}$ & 2.6 & 8.5 & 2.96 & $221 \mathrm{~b}$ \\
V5 & 40 & $60 \mathrm{a}$ & 2.7 & 5.8 & 1.90 & $111 \mathrm{c}$ \\
\hline
\end{tabular}

Chi-square is used for survival rate and t-test for growth rates values. Numbers bearing the same letter are not significantly different at $.05 . \quad F_{86}^{4}=6.89$ on final weights.

A second trial was conducted from the same kind of formulation as above but fish meal is replaced by a fat-free fish meal called Protanimal. In that way, lipids were contributed only by cod liver oil which corresponds to the best source of lipids for shrimp. Juveniles had a smaller starting weight, $.4 \mathrm{~g}$ on the average. There is no significant difference in growth $(p=0.5)$ between diet $V 3$ (A) and the others ( $B, C$ or D) (Table 10). B contained 58 activated sludge added to $A ; C$ had a mineral supplement with crustacean shells and $D$ was supplemented with vitamins.

Table 10. Performances Obtained with Penaeus merguiensis Fed on Artificial Diets after 12 Weeks Experiment from .4 g Average Animals at a Stocking Density of 50 Shrimp/Tank (Curve 2, Fig. 1)

\begin{tabular}{ccccccc}
\hline $\begin{array}{c}\text { Artificial } \\
\text { Diet }\end{array}$ & $\begin{array}{c}\text { Initial } \\
\text { Number }\end{array}$ & $\begin{array}{c}\text { Survival } \\
\text { Rate } \\
(\mathrm{z})\end{array}$ & $\begin{array}{c}\text { Average } \\
\text { Initial } \\
(g)\end{array}$ & $\begin{array}{c}\text { Final } \\
\text { Weight } \\
(g)\end{array}$ & SD & $\begin{array}{c}\text { Growth } \\
\text { Rate } \\
(8)\end{array}$ \\
\hline A & 100 & $74 b$ & .39 & 2.94 & .67 & $662 \mathrm{a}$ \\
B & 102 & $60 \mathrm{~b}$ & .41 & 2.93 & .97 & $614 \mathrm{a}$ \\
C & 101 & $66 \mathrm{~b}$ & .40 & 2.85 & .76 & $620 \mathrm{a}$ \\
D & 50 & $70 \mathrm{~b}$ & .39 & 2.68 & .79 & $587 \mathrm{a}$ \\
\hline
\end{tabular}

For each column, numbers bearing the same letter are not significantly different. A--standard artificial diet (V3); B--diet A plus activated sludge; C--diet $A$ plus crustacean shells; D--diet $A$ enriched with ascorbic acid. SD--standard deviation of the mean.

\section{DISCUSSION}

Penaeus merguiensis seems to have high protein requirements as found by Beard et al. (1977). This need puts the present species nearer $P$. japonicus (Deshimaru and Shigueno, 1972) than $P$. monodon or $F$. vannamei (Aquacop, 1976). Note that such results were from juveniles below $3.0 \mathrm{~g}$. But an evolution in protein need could exist because larger animals until 10-12 $\mathrm{g}$ show good growth promotion with a lower protein 
according to size as observed by Regnault and Luquet (1974) and on Palaemon serratus by Cuzon (1970).

Milk casein as a sole source of protein supplies each essential amino acid but growth promotion stays below that expected with artificial diet. This is probably due to lack of some unknown growth factor in the milk casein diet. A mixture of carbohydrates with monosaccharides seems to inhibit the growth compared to the same mixture where glucose is absent. It could be related to the very low level of glucose in hemolymph $(0.08 \mathrm{~g} / \mathrm{liter})$. Andrews and sick (1971) noticed with $P$. setiferus an inhibitor effect of glucose and growth was enhanced with starch. When the protein level in the diet is too low, the influence of the carbohydrate source is minimized by the deficiency in protein content. The growth is so low that there is no difference whatever in sugar retained.

Under the conditions of experimentation antibiotics added to a purified diet do not seem to improve survival rate or growth promotion. Antibiotics which may enhance assimilation of a diet when favoring the growth of nutrient-synthesizing microorganisms (Scott et al., 1969), do not improve availability of nutrients in the intestinal tract of $P$. merguiensis.

Lipid requirements are satisfied for Penaeus merguiensis if an oil of animal origin is chosen rather than a vegetable oil. A fish oil such os cod liver oil in sufficient quantities (78) brings in the polyunsaturated fatty acids which are essential for penaeid growth (Kanazawa et al., 1977; Aquacop, 1976). Shark liver oil appears inadequate, mainly because of the presence of squalene in high concentration (Kayama, 1964).

Mineral mixtures did not limit growth when a convenient level (8108) is added to the diet; it is possible to enhance growth promotion when an oligoelement such as magnesium is incorporated with other minerals at 15-20 of total premix. This value corroborates results on Penaeus japonicus (Sasaki, personal communication).

A supplement of commercial vitamin mixture to adjust to levels of vitamins given by Kanazawa et al. (1970) is not particularly efficient if ascorbic acid, choline or inositol are considered. For example, 5 times more ascorbic acid in a diet compared to another has no effect on growth. But when a premix is quite unbalanced for a marine organism it fails completely (see mixture No. 5, Table 8). An optimum composition in vitamins is important for reproductive results. Protector commercial mixture seems to provide each essential vitamin.

Results of growth on an artificial diet of juveniles are satisfying (Fig. 1) under controlled conditions and during a valuable period. The performances have been increased in modifying the formula diet up to a profile like that in food $A$. The growth promotion with curve No. 1 is similar to other data in tanks (Wickins, 1975, personal communication) or in grow-out ponds (Gundermann and Popper, 1975) at low density. The growth curves obtained with Penaeus merguiensis fed on natural food such as mussel flesh are slightly better than those obtained on a compounded diet. With another species like $P$. japonicus it is therefore possible to view as efficient such an artificial food as chopped mollusk flesh (Shigueno, 1975) or sometimes a slightly superior growth promotion. More nutritional information is required for $P$. merguiensis to elaborate a more effective artificial diet. In Tahiti, in grow-out tanks the 
culture never reaches a significant step even on a performant diet like the Japanese diet which contains high quality proteins. Other factors interfering in grow-out ponds are diseases (Aquacop, 1977a), which could explain some bad crops. Principally because of a lack of significant results on a larger scale, $P$. merguiensis will not remain a candidate species for aquaculture compared to a more hardy species like $P$. monodon (Aquacop, 1977b).

\section{SUMMARY}

Several experiments have been carried out on Penaeus merguiensis in small tanks under controlled environmental conditions at a stocking density of 60 animals $/ \mathrm{m}^{2}$, to determine optimal nutritional requirements of this penaeid species. With purified diets it is possible to obtain good growth and survival rates with a 508 casein basal diet. Polysaccharides are more efficient than monosaccharides as an energy source in the diet. Different dietary oils promote good growth; using mainly fish oil brings in polyunsaturated fatty rcids to the shrimp. Results obtained with varying mineral mixtures are quite similar although a magnesium level around 38 is optimum. Vitamin mixtures, when unbalanced, have a drastic influence on shrimp growth. Kanazawa's formula appears similar to commercial vitamin mixtures and can be slightly improved by supplement. Survival rates never exceed 708 and growth promotion stays at a minimum. On a comparative basis, information obtained on nutritional requirements of this species can help to arrive at an artificial diet. Principal characteristics must be maintained in the formulation of this diet where the main changes lie in the substitution of casein by other protein sources.

The second step in experimentation consisted of elaborating diets which gave varying results in larger scale experiments at a stocking density of $20 \mathrm{shrimp} / \mathrm{m}^{2}$. The best of these can reach a conversion ratio of $1.4: 1$ in 12 weeks of experimentation. In open field ponds such results have not yet been obtained, due partly to some disease problems. Most of the constraints found for shrimp diet formulation in this study can be adapted for other penaeid species.

\section{LITERATURE CITED}

Andrews, J. W., and L. V. Sick. 1972. Studies on the nutritional requirements of penaeid shrimp. Proceedings World Mariculture Society $3: 403-414$.

Aquacop. 1975. Maturation and spawning in captivity of penaeid prawns. Proceedings World Mariculture Society 6:123-132.

Aquacop. 1976. Résultats expérimentaux sur $P$. japonicus: spécificité des besoins en protéines. FAO Meeting, Kyoto, Japan. FIR:AQ/ Conf./76/E.42.

Aquacop. 1977a. Observations on diseases of crustacean cultures in Polynesia. Proceedings World Mariculture Society 8:685-703.

Aquacop. 1977b. Reproduction in captivity and growth of Penaeus monodon Fabricius in Polynesia. Proceedings World Mariculture Society $8: 927-945$. 
Beard, T. W., J. F. Wickins, and D. R. Arnstein. 1977. The breeding and growth of $P$. merguiensis de Man in laboratory recirculation systems. Aquaculture 10:275-289.

Cuzon, G. 1970. Alimentation et êlevage de Palaemon serratus, Crangon crangon et Penaeus kerathurus. Thèse Doct. Spéc. Océan. biol., Université Aix-Marseille, pp. 1-107.

Deshimaru, O., and $\mathrm{K}$. Shigueno. 1972. Introduction to the artificial diet for prawn $P$. japonicus. Aquaculture $1(1): 115-133$.

Gundermann, N., and D. Popper. 1975. Experiment in growing Penaeus merguiensis (de Man, 1888) in a fish pond in Fiji. Aquaculture $6: 197-198$.

Kanazawa, A., M. Shimaya, M. Kawasaki, and K. Kashiwada. 1970. Nutritional requirements of prawn. I. Feeding on artificial diet. Bulletin Japanese Society Scientific Fisheries 36:949-954.

Kanazawa, A., S. Teshima, and S. Tokiwa. 1977. Nutritional requirements of prawn. VII. Effect of dietary lipids on growth. Bulletin Japanese Society Scientific Fisheries 43:849-856.

Kayama, M. 1964. Fatty acid metabolism in fish. Bulletin Japanese Society Scientific Fisheries 30:647-659.

New, M. B. 1976. A review of dietary studies with shrimp and prawns. Aquaculture 9:101-144.

Regnault, M., and P. Luquet. 1974. Besoins en protéines de la crevette grise Crangon crangon (L.) au cours de sa croissance. Annales Nutition et Alimentation $28(6)$.

Shigueno, K. 1975. Shrimp culture in Japan. Association for International Technology Promotion, Tokyo, Japan. 153 pp.

Schwartz, D. 1963. Méthodes statistiques à l'usage des médecins et des biologistes. Flammarion Editeur, Paris.

Scott, M. L., M. C. Nesheim, and R. J. Young. 1969. Nutrition of the Chicken. M. L. Scott and Associates, Ithaca, N.Y. 